\title{
FAKTOR-FAKTOR YANG MEMPENGARUHI PEMAKAIAN JILBAB DI KALANGAN MAHASISWI UNIVERSITAS SWADAYA GUNUNG JATI KOTA CIREBON
}

\author{
Setia Budiyanti, S.Ag., MH \\ setiabudiyanti77@gmail.com \\ Universitas Swadaya Gunung Jati, Cirebon
}

\begin{abstract}
Islam represent the religion having system aqidah arranging all religious service to Allah of SWT and fellow being. Perhaps the inclusive of in it dressy rule for people islam more special for Muslimah. Dress muslim is obligation for Muslimah in running syari'at Islam that is close aurat. This research aim to to know the factor influencing undergraduate in dress muslim and to know the relation dress muslim with the understanding and compliance run the other syari'at Islam. Technique of data collecting use the kuesioner propagated to Self-Supporting University undergraduate of Universitas Swadaya Gunung Jati Cirebon. Result of research obtained by $64 \%$ undergraduate which dress muslim have followed the religious education and $36 \%$ have never followed the religious education. About $36 \%$ undergraduate feel fluent read the Al-Qur'An and 64\% undergraduate is not fluent read the Al-Qur'An. There are positive correlation between use jilbab with the other religious service execution. About $36 \%$ undergraduate dress muslim influenced by the school, $21 \%$ undergraduate dress muslim of because direct understanding of Islam teaching, and fresh $14 \%$ undergraduate dress muslim of because parent motivation and environmental.
\end{abstract}

Keyword: Dress Muslim, understanding of religion islam.

\begin{abstract}
Abstrak
Islam merupakan agama yang mempunyai sistem aqidah yang mengatur segala ibadah kepada Allah SWT dan sesama manusia. Tentunya termasuk di dalamnya ketentuan berpakaian bagi umat islam lebih khusus bagi Muslimah. Berjilbab adalah kewajiban bagi Muslimah dalam menjalankan syari'at agama Islam yaitu menutup aurat. Penelitian ini bertujuan untuk mengetahui faktor yang mempengaruhi mahasiswi dalam berjilbab dan untuk mengetahui hubungan berjilbab dengan pemahaman dan kepatuhan menjalankan syari'at agama Islam lainnya. Teknik pengumpulan data menggunakan kuesioner yang disebarkan kepada mahasiswi Universitas Swadaya Gunung Jati Kota Cirebon. Hasil penelitian diperoleh 64\% mahasiswi yang berjilbab pernah mengikuti pendidikan keagamaan dan $36 \%$ tidak pernah mengikuti pendidikan keagamaan. Sekitar 36\% mahasiswi merasa lancar membaca Al-Qur'an dan 64\% mahasiswi tidak lancar membaca Al-Qur'an. Terdapat korelasi positif antara penggunaan jilbab dengan pelaksanaan ibadah lainnya. Sekitar 36\% mahasiswi berjilbab dipengaruhi sekolah, $21 \%$ mahasiswi berjilbab karena pemahaman langsung ajaran agama Islam, dan sekar $14 \%$ mahasiswi berjilbab karena dorongan orang tua dan lingkungan.
\end{abstract}

Kata Kunci: Jilbab, Pemahaman Agama Islam 


\section{PENDAHULUAN}

Agama islam merupakan agama yang memiliki sistem aqidah yang implementasinya melalui beberapa ketentuan syari'at untuk beribadah kepada Allah SWT dan ibadah sesama umat manusia. Oleh karena Islam sebagai agama yang memiliki sistem aqidah maka Islam senantiasa memberikan tuntunan untuk kehidupan yang dijalainya mulai dari hal terkecil sampai beberapa hal urusan besar. Dalam agama islam terdapat beberapa ketentuan dan aturan untuk umat Islam dalam menjalankan kehidupannya seperti ajaran berakhlak, berpakaian, berdagang, berpolitik, hingga mengatur kenegaraan telah ditetapkan oleh ajaran agama Islam.

Islam telah menjelaskan segala aspek kehidupan manusia. Hal ini dijelaskan bahwa Allah SWT telah mengutus Nabi Muhammad Saw sebagai pembawa rahmat bagi seluruh alam. Firman Allah SWT Pada surat Nahl 89 dengan terjemahan bahwa "Dan Kami telah menurunkan kepadamu (Nabi Muhammad) Al-kitab untuk menjelaskan segala sesuatu dan petunjuk serta rahmat dan kabar gembira bagi orang muslim”. Ajaran Islam yang mengatur ketentuan berperilaku oleh setiap umat muslim bahwa hal ini mempunyai makna adab tidak terpisah dengan aktivitas dan amalan manusia. Karena tanpa adanya aturan yang ada di Islam maka segalanya tidak bermakna.

Ajaran agama Islam telah mengatur keseimbangan antara hak dan kewajiban sebagai manusia, juga antara individu dengan Negara dengan tujuan menciptakan kehidupan yang aman dan sejahtera. Ibnu Taimiyah menerangkan manfaat islam dan umat islam begitu besar dalam kehidupan. Islam mengajak untuk selalu berperilaku pada kebajikan, hal ini sesuai dengan firman Allah SWT yang artinya "Dan orang-orang yang beriman, laki-laki dan perempuan. Sebagian dari mereka menjadi penolong bagi sebagian yang lainnya. Mereka menyuruh yang ma'ruf dan mencegah yang mungkar (At-Taubah: 71).

Umat islam dalam menjalankan kehidupan sehari-hari selalu diberikan batasan dan tuntunan oleh Allah SWT. Dengan kata lain Allah SWT lebih menyukai orangorang yang selalu mensucikan diri dari segala perbuatan yang tidak baik atau merugikan orang lain. Artinya bahwa manusia harus saling menjaga menghormati dimulai dari hal kecil termasuk dalam hal berpakaian.

Islam sangat memuliakan manusia dengan membedakan batas antara aurat lakilaki dan perempuan adalah bertujuan untuk menjaga dan memuliakan manusia dalam 
kehidupan. Di samping itu, menjaga aurat sebagai bentuk harga diri dan menumbuhkan nilai budi pekerti. Aurat merupakan salah satu harga diri manusia yang harus dijaga. Oleh karena itu, aurat dalam islam tidak memperbolehkan saling melihat antara laki-laki dengan perempuan atau bahkan sesama jenis (Fachruddin, 1984) character building dan basic personality manusia, harus melalui penanaman disiplin yang tinggi, agar manusia memiliki kekuatan jiwa, atau mental yang tinggi, tidak mudah menyerah dengan keadaan. Dan manusi dilatih untuk taat terhadap hukum yang berlaku, manusia dididik mengenal reward and punishment (ganjaran dan hukuman), agar manusi memiliki tanggung jawab terhadap apa saja yang ia kerjakan dan lakukan.(Sada, 2015)

Untuk menjaga aurat perempuan, maka kaum perempuan dianjurkan untuk menutup auratnya dengan berpakaian yang baik atau biasa disebut berjilbab. Menggunakan jilbab artinya menutup aurat mulai dari rambut hingga bagian dada yang diwajibkan bagi seorang perempuan. Allah SWT berfirman Annur ayat 21 yang artinya "Katakanlah kepada wanita yang beriman, Hendaklah mereka menahan pandangannya dan memelihara kemaluannya dan janganlah mereka menampakkan perhiasannya, kecuali yang (biasa) nampak daripadanya. Dan hendaklah mereka menutup kain kudung ke dadanya dan janganlah menampakkan perhiasannya kecuali kepada suami mereka atau ayah atau ayah suami mereka atau putra mereka". Dengan demikian jelas bahwa dalam aturan berpakaian khususnya bagi perempuan sudah ada ketentuannya dalam agama Islam.

Menutup aurat dengan berjilbab ban perkara mudah. Hal ini tergantung kepada pemahaman perempuan akan berbagai hukum Islam termasuk akan syari'at Islam lainnya. Berjilbab akan memiliki korelasi terhadap pemahaman dan pelaksanaan ibadahibadah lainnya.

Dalam perkembangan di masyarakat, masih terdapat keberagaman pengetahuan dan sikap kaum perempuan terhadap jilbab. Sebagian dari perempuan telah mampu menggunakan jilbab dan sebagian lainnya masih belum mampu menggunakan jilbab atau bahkan belum memahami pentingnya menutup aurat. Banyak faktor yang mungkin terjadi di kalangan perempuan masih belum berjilbab. Dari hasil pengamatan terhadap mahasiswi kampus Unswagati kota Cirebon dalam perkembangan umur mahasiswi merupakan fase mencari jati diri. Kondisi ini berimbas pada penggunaan berpakaian sebagai pencitraan diri yang sekaligus mencerminkan citra lingkungan dan keluarga. 
Oleh karena itu, penelitian ini dilakukan bertujuan untuk mengetahui faktor-faktor yang mempengaruhi mahasiswi dalam berjilbab, terutama apabila dikaitkan dengan pemahaman dan kepatuhan dalam menjalankan perintah agama Islam yaitu menjaga aurat.

Achmadi dalam pengantarnya menyebutkan bahwa, pendidikan kita sangat kebarat-baratan maka"Ideologi pendidikan dimaksudkan untuk memberikan alternatif landasan pendidikan di tengah-tengah membanjirnya berbagai ideologi kontemporer seperti pluralism, posmodernisme, feminism, dll”. (Achmadi, 2004) Pendidikan semestinya menjunjung tinggi karakternya untuk menjadikan manusia yang humanis. Humanisme merupakan konsep kemanusiaan yang sangat berharga karena konsep ini memihak kepada manusia, menjunjung tinggi harkat dan martabat manusia, dan memfasilitasi kebutuhan-kebutuhan manusia untuk memelihara dan menyempurnakan keberadaannya sebagai makhluk paling sempurna. Ideologi pendidikan kita harus mengedepankan firman Allah, “... Sayangilah keduanya (orang tua)sebagaimana mereka telah mengasuhku (mendidiku) sejak kecil. (Q.S. al-Isra; 24). Hadits Nabi, Didiklah anak-anakmu atas tiga perkara; mencintai nabimu, mencintai keluarganya, dan membaca Al-Quran. (HR. ad-Dailamy). Pendidikan berideologi Islam hendaklah dapat memenuhi tampilan-tampilan islami, dimulai dari cara berpakaian guru, siswa, tenaga administrasi, hingga pada proses-proses teknis pembelajaran, harus berorientasi islami untuk menunjukkan rakhmatan lil alamin, bahwa dengan nilai-nilai kemanusiaan islami akan memberikan rahmat kepada semua makhluk di sepanjang waktu.

Amiruddin, Khairudin, dan Irwan nasution dulu disebutkan bahwa manajemen pendidikan sebagai mesin penguasa untuk melakukan indoktrinasi kekuatan kekuasaannya. Bahkan disebutkan bahwa pendidikan tidak berdaya, hingga tenaga kependidikan ditempatkan sebagai aparat Negara yang harus memberikan andil dalam melanggengkan kekuasaan penguasa. Melalui pendidikan berbasis sekolah, maka tuntutan profesionalisme kepala sekolah dan guru perlu ditingkatkan. Melalui pendidikan berbasis sekolah maka kepala sekolah memiliki keleluasaan dalam mengadopsi sejumlah inovasi yang kini berkembang sangat cepat. Perubahan masyarakat melalui sektor pendidikan termasuk strategis dan harus menjadi prioritas. Model birokrasi dan pengelolaan sekolah yang dinamis, responsif pada ilmu, teknologi, 
dan kebutuhan masyarakat, menjadi kunci suksesnya pendidikan.(Amiruddin, Khairudin, \& Nasution, 2006)

Menurut Martinis Yamin, tujuan merupakan sasaran yang harus dicapai oleh siswa dalam proses pembelajaran. Tujuan pendidikan harus bermanfaat bagi siswa, yang merupakan bentuk perilaku yang bisa diukur. Dalam silabus pelajaran, tujuan ini disebut khusus dan dalam istilah kompetensi disebut indikator. Standar mutu pendidikan yang sudah dengungkan, yang diukur melalui standar nilai yang harus dicapai dalam UAN. UAN mungkin bisa memotret mutu dan keseragaman, akan tetapi problem remaja dan remuknya jati diri remaja, juga tanggung jawab pendidikan. Dorongan (motivasi) seorang guru umumnya menjadi nilai pribadi yang besar sehingga siswa dapat sukses di kemudian hari. Perbedaan individu mulai kecerdasan, bakat (attitude), kesehatan dan kesempurnaan fisik, keadaan keluarga, hingga kemampuan siswa dalam penyesuaian sosial. (Yamin, 2007)

Soedjatmoko mengajak untuk kembali meninjau jalannya pembangunan, agar berkembangnya teknologi tidak menimbulkan kerusakan ekologis. Disinilah kita memerlukan para sarjana muslim yang beretika, bahwa apa yang diambilnya senantiasa tidak berlebihan. Soedjatmoko menambahkan, bahwa problem ini diawali oleh suatu model pendidikan dan pembangunan yang mendorong mengalirnya masyarakat dari desa-desa ke kota. Mereka tidak memahami pentingnya membangun desa. Di kota, masyarakat lebih bersifat individualistis dan ekonomis, sehingga nilai-nilai agama kurang mendapatkan perhatian (Munandar, 1995)

Berjalannya hak-hak umat Islam dalam menjalankan syariat agama, perlu ditopang oleh kepribadian para pemimpin yang berlandaskan Islam. Hadari Nawawi menyebutkan di sinilah kita akan mendapati pemimpin yang berpikir efektif dalam menetapkan keputusan. Berjilbab, karena merupakan kewajiban bagi setiap muslimah, maka hendaklah dapat dijalankan oleh setiap individu dimana pun mereka berada, bekerja, dan menjalankan usaha.

Pendidikan sosial menitik beratkan pada usaha untuk mengembangkan kepribadian. Kehidupan sosial yang dianggap sebagai struktur social dan fungsional sehingga ada atau hilang akan berjalan dengan sendirinya. Jilbab datang menjadi kebutuhan dan telah menempati lebih dari 50\% pada mahasiswa Unswagati karena 
kesadaran akan syari'at Islam meningkat dan tidak bisa dicegah. Cara pandang dan sistem nilai berubah, dulu berjilbab dianggap kampungan dan sekarang dikatakan sebagai kesadaran berprilaku. Dulu berjilbab merupakan nilai kampungan dan sekarang desa dan kota berjilbab. Jilbab dan desain jilbab tidak lagi memasuki ranah pengrajin, akan tetapi telah memasuki ranah industri. Sosialisasi pemuda dimulai sejak usia 10 tahun yang dimuali dari lingkungan keluarga, tetangga, dan masyarakat umum. (Munandar, 1995)

Berdasarkan penelitian terdahulu, telah dilakukan beberapa penelitian dalam mengkaji mengenai penggunaan jilbab (Fakhruroji, 2015; Hela, Alimi, \& Mustofa, 2013; Istiani, 2015; Musthofa, 2017; Rahayu, 2016; Rahnama, Arani, \& Arani, 2015; Saprudin, Mushlihin, \& Narulita, 2016; Sopiah, Khobir, Zuhri, \& Mufidah, 2013) serta telah dilakukan penelitian mengenai pentingnya melihat faktor-faktor suatu fenomena (Aprilia, 2012; Herdi, Kartadinata, \& Taufiq, 2917; Maghfiroh, 2015; Neliana, 2017; Setyawan \& Aryani, 2017; Syaiful \& Sari, 2017) namun belum ada penelitian yang mengkaji faktor faktor yang mempengaruhi pemakaian jilbab di kalangan mahasiswa.

Berdasarkan penelitian yang telah dilakukan sebelumnya, keterbaruan dalam penelitian ini terletak pada bagaimana faktor faktor yang mempengaruhi pemakaian jilbab di kalangan mahasiswa yang dilakukan di Universitas Swadaya Gunung Jati Kota Cirebon

\section{METODE PENELITIAN}

Jenis penelitian yang digunakan adalah model penelitian kualitatif dengan kajia literatur. Tempat penelitian dilaksanakan di lingkungan kampus Universitas Swadaya Gunung Jati (Unswagati) Kota Cirebon, yaitu di fakultas-fakultas dan pada mahasiswi tingkat I. Dengan demikian, penelitian dilaksanakan atau mewakili oleh mahasiswi dari ke tiga lingkungan kampus yaitu di Kampus I, Kampus II Jln. Perjuangan, dan Kampus III yang baru. Penelitian ini dilaksanakan selama 6 bulan (semester ganjil Tahun Akademik 2010-2011) yaitu Bulan Oktober 2010 sampai Maret 2011.

Survey dilakukan untuk melakukan pengambilan data primer. Teknik pengumpulan data dilakukan dengan memberikan angket (daftar isian) kepada seluruh mahasiswi responden. Data sekunder merupakan berbagai laporan dan catatan dari 
fakultas atau dari instansi lainnya, dalam rangka melengkapi data yang diperlukan, baik sebagai data awal maupun untuk kepentingan analisis.

Data yang sudah terkumpul, selanjutnya dilakukan analisis secara deskriptif dengan cara membahas atas bobot persentase sikap, kebiasaan, atau tanggapan yang diberikan oleh mahasiswi.

\section{HASIL DAN PEMBAHASAN}

Sebagai Muslimah menggunakan jilbab dengan tujuan menutup aurat merupakan suatu kewajiban. Namun demikian, penggunaan jilbab mulai berkembang pada tahun 1980-an dan masih di lingkungan terbatas atau hanya kalangan tertentu saja. Seiring perkembangan zaman, saat ini penggunaan jilbab sudah dilakukan oleh berbagai kalangan. Kini banyak Muslimah menggunakan jilbab dalam berbagai aktivitas sosial.

Pada dasarnya penggunaan jilbab berkembang di mulai dari keluarga islami, sebuah keluarga yang menganjurkan segala aktivitas atas dasar ajaran agama Islam. Dengan kata lain, penggunaan jilbab bermula pada aktivis muslim, untuk berusaha menegakkan syari'at agama Islam di kehidupan keseharian mereka. Kemudian dilakukan oleh keluarga Kyi, ustad dan guru-guru agama, serta keluarga yang sudah menjalankan ibadah haji.

Pemakaian jilbab oleh anak sekolah atau siswa dimulai tahun 1990-an. Saat itu banyak muncul perdebatan oleh guru dan kepala sekolah dengan beberapa alasan tidak sejalan dengan seragam sekolah saat itu. Bahkan zaman sekarang, masalah penggunaan jilbab masih dirasakan kaum Muslimah ketika menjadi profesi atau karyawan. Tekanan dan peraturan perusahaan sering menjadi batasan dalam menggunakan jilbab di lingkungan kerja.

Berdasarkan anggapan atau respon terhadap penggunaan jilbab di kalangan mahasiswi Unswagati Kota Cirebon memberikan sedikit gambaran mengenai penggunaan jilbab di kalangan remaja pada umumnya. Terdapat sekitar $64 \%$ mahasiswi yang berjilbab pernah mengikuti pendidikan keagamaan di madrasah atau sejenisnya. Sedangkan sekitar 36\% mahasiswi lainnya tidak pernah mengikuti pendidikan keagamaan di madrasah atau sejenisnya. Namun demikian, mereka yang merasa lancar (fasih) dalam membaca Alqur'an baru 36\% sedangkan sebagian besarnya (64\%) 
menyatakan belum begitu lancar. Tampilan yang disebut lancar atau tidak lancar, mungkin berkenaan dengan kesanggupannya apabila diperintah membacakan ayat Alqur'an di depan umum. Hal ini juga tampak bahwa di dalam acara acara musabaqah tilawatil qur'an yang dilakukan antara mahasiswi di Unswagati, jumlah peserta sangat sedikit yang memiliki kesiapan berpartisipasi sebagai peserta. Dalam acara-acara kelembagaan di Universitas maupun di fakultas, para mahasiswi yang fasih menyajikan qori'ah (membaca dengan nada lagu) sangat sedikit.

Pemakaian jilbab oleh mahasiswi berkorelasi positif dengan pelaksanaan ibadah lainnya termasuk dengan shalt fardhu. Mahasiswi yang menggunakan jilbab pada umumnya sudah patuh dalam menjalankan kewajiban shalat fardhu. Sebanyak $97 \%$ mereka menyatakan pasti mendirikan shalat fardhu dan hanya 3\% yang menyatakan terkadang masih lupa. Diantara mahasiswi, belajar shalat dilakukan sejak di sekolah Taman Kanak-kanak (TK), ada yang setelah di Sekolah Dasar (SD), dan sebagian baru mulai di Sekolah Lanjutan Pertama (SMP). Mereka yang belajar di Madrasah Diniyah Islamiyah (MDI), Madrasah Tsanawiyah (MTs), dan Madrasah Aliyah (MA), pada umumnya sudah lebih awal mendirikan shalat, atau paling tidak sejak di Madrasah Diniyah.

Banyak di kalangan mahasiswi yang sudah mengerjakan kewajiban shalat dan terbiasa memakai jilbab namu tidak semua sudah hafal bacaan shalat wajib. Berdasarkan hasil penelitian, sekitar $71 \%$ mahasiswi yang menyatakan sudah hafal dan 29\% lainnya menyatakan hafal sebagian. Kondisi ini tentu menjadi tantangan dan tanggung jawab kita sebagai para pembina mereka.

Menjalankan ibadah shalat diperlukan proses pembelajaran dan begitu juga dengan ibadah shaum atau berpuasa. Para mahasiswi menjalan dan belajar ibadah shaum di mulai sejak sekolah dasar, ada mungkin yang mulai setelah masuk sekolah lanjutan tingkat pertama atau ketika sudah sekolah menengah atas. Tentunya hal ini bisa terjadi karena faktor lingkungan dan latar belakang pendidikan masing-masing.

Selain ibadah mahdhoh, mahasiswi juga mengenal berbagai jenis ibadah lainnya seperti berbakti atau berbuat baik kepada kedua orang tua. Berkenaan dengan hal tersebut, terdapat sebanyak $43 \%$ mahasiswi yang mengetahui kemana saja biasanya orang tua mereka memberikan infaq dan sodaqohnya. Adapun sebanyak 57\% dari 
mereka merasa tidak tahu, kemana saja orang tua mereka memberikan infaq dan sodaqohnya.

Keyakinan terhadap memeluk agama banyak dilandaskan atas diturunkan oleh orang tua kepada anak-anaknya. Kasus ini di pandang baik dan benar oleh orang tua yang menurunkan agama atau keyakinan kepada anak-anaknya meskipun mungkin ada yang bersifat pemaksaan. Namun demikian. Di kehidupan sehari-hari nilai-nilai universal yang ada di agama Islam umumnya kurang dipahami. Sebagian masyarakat menjalankan ajaran agama Islam berdasar pada hal-hal yang dianggap lebih mudah dan sudah umum dikerjakan. Seperti berjilbab oleh kalangan Muslimah di wilayah Kota Cirebon baru berkembang pada tahun 1990-an dan tersebar hingga saat ini. Di lingkungan pendidikan, penggunaan jilbab relatif lebih cepat terutama didukung oleh sikap dan pemahaman guru serta pimpinan sekolah.

Berdasarkan hasil penelitian, beberapa instrumen yang mempengaruhi mahasiswi menggunakan jilbab sebagian besar dipengaruhi oleh sekolah (36\%). Dorongan diri sendiri yang terbangun melalui pemahaman langsung atas ajaran islam menempati urutan ke dua (21\%). Adapun dorongan orang tua, lingkungan keluarga, dan lingkungan masyarakat, masing-masing sebesar $14 \%$.

Jilbab yang saat ini dipakai, tampaknya belum menjadikan pakaian sepenuhnya karena pemakaian jilbab ditempat umum lainnya sebesar $43 \%$ masih suka dilepas atau tidak berjilbab. Dengan demikian dapat dikatakan bahwa pemakaian jilbab yang permanen digunakan untuk berbagai kepentingan di luar rumah hanya 57\%. Kondisi ini masih membutuhkan perjuangan melalui pemahaman yang kuat dari sumbernya yaitu Alqur'an.

Berdasarkan jawaban para mahsiswa, diantara mereka yang sudah mengetahui langsung dari sumbernya yaitu Al-Qur'an baru 20\%. Sebagian besar (80\%) mahasiswi belum tahu ayat-ayat Al-Qur'an yang memerintahkan agar wanita menutup kerudungnya hingga ke dada. Hal ini menunjukkan bahwa sosialisasi penerapan syari'at islam khususnya masalah berjilbab belum secara sistematis mendorong Muslimah untuk menutup aurat dengan berjilbab. Dalam pemakaian secara umum masih bersifat sukasuka dan tidak menjadi suatu kewajiban. 
Pemakaian jilbab oleh sebagian mahasiswi sebenarnya sudah dilakukan sejak mereka duduk di bangku sekolah dasar. Namun demkian, juga banyak yang mulai memakainya setelah menjadi siswa SLTA. Dengan demikian, fase awal memakai jilbab oleh para mahasiswi berbeda-beda, ada yang sudah melaksanakan 7 tahun yang lalu dan ada pula yang baru satu tahun. Sedangkan dalam keluarga mereka, pemakaian jilbab baru mencapai $21 \%$, sebagaian besar (58\%) baru dipakai oleh sebagaian anggota keluarga, 14\% kadang-kadang dipakai dan 7\% keluarganya tidak memakai jilbab. Dengan demikian, sebanyak 7\% dari mahasiswi yang memakai jilbab di kampus.

Tanggapan dan respon tentang berjilbab pada umumnya adalah positif dalam arti bagus, anggun, cantik, sopan, indah dan cocok digunakan. Tanggapan ini sangat positif karena walaupun mereka paham bahwa pemakai jilbab tidaklah identik dengan wanita solehah sepenuhnya, akan tetapi mereka tidak berani untuk menyatakan bahwa yang menggunakan jilbab itu tampak tidak baik. Demikian, sesungguhnya hal ini suatu cerminan bahwa, pakaian yang dikehendaki oleh Allah SWT., akan dikatakan baik oleh manusia dan pasti baiknya disisi Allah SWT. Dan, tanggapan ini telah mencerminkan salah satu kebenaran firman Allah SWT., khususnya berkaitan dengan pakaian.

\section{SIMPULAN DAN SARAN}

Berdasarkan data penelitian, terdapat sekitar $64 \%$ mahasiswi yang berjilbab pernah mengikuti pendidikan keagamaan seperti madrasah dan sisanya 36\% tidak pernah mengikuti pendidikan keagamaan seperti madrasah. Mahasiswi yang lancar membaca Al-Qur'an tergolong masih rendah sekitar 36\% sedangkan sebagian besar 64\% menyatakan belum lancar membaca Al-Qur'an. Pemakaian jilbab yang di lakukan oleh kalangan mahasiswi mempunyai korelasi yang positif dengan pelaksanaan agama lainnya seperti shalat fardhu. Hal ini diperkuat dengan hasil penelitan sekiat $97 \%$ mahasiswi melaksanakan shalat fardhu dan 3\% lainnya menyatakan kadang-kadang menjalankan shalat fardhu.

Dari hasil penelitian yang dilakukan maka peneliti memberikan saran bahwa perlu adanya upaya pemahaman yang kuat terhadap ajaran agama Islam yang terutama mempelajari A-Qur'an khususnya dalam aturan berpakaian bagi kaum Muslimah. Sehingga pembiasaan berjilbab dapat lebih meningkat di kalangan kampus dan tempat umum yang biasa para Muslimah melakukan interaksi sosial. 


\section{DAFTAR PUSTAKA}

Achmadi. (2004). Ideologi Pendidikan Islam. Yogyakarta: Pustaka Pelajar.

Amiruddin, Khairudin, \& Nasution, I. (2006). Manajemen Pendidikan Berbasis Sekolah. Jakarta: Quantum Teaching.

Aprilia, F. (2012). Faktor-faktor Yang Mempengaruhi Minat Berwirausaha Pada Siswa Kelas XII SMK Negeri 1 Kandeman Kabupaten Batang Tahun 2011/2012. Economic Education Analysis Journal, 1(2), 1-5.

Fachruddin, F. M. (1984). Aurat dan Jilbab Dalam Pandangan Mata Islam. Jakarta: CV. Pedoman Ilmu Jaya.

Fakhruroji, M. (2015). Transformasi Konsep Diri Muslimah Dalam Hijabers Community. Al-Tahrir, 15(2), 431-450.

Hela, R. M., Alimi, M. Y., \& Mustofa, M. S. (2013). Pemakaian Jilbab Kreasi Baru Di Kalangan Mahasiswi (Studi Kasus Terhadap Mahasiswi Universitas Negeri Semarang). Solidarity: Journal of Education, Society and Culture, 2(2), 95-104.

Herdi, H., Kartadinata, S., \& Taufiq, A. (2917). Faktor-Faktor yang mempengaruhi kearifan konselor menurut perspektif calon konselor etnis jawa. Jurnal Penelitian Dan Evaluasi Pendidikan, 21(2), 162-174.

Istiani, A. N. (2015). Kontruksi Makna Hijab Fashion Bagi Moslem Fashion Blogger. Jurnal Kajian Komunikasi, 3(1), 48-55.

Maghfiroh. (2015). Faktor faktor yang mempengaruhi niat membeli makanan kemasan berlabel halal LPPOM-MUI. Jurnal Economia, 11(2), 169-176.

Munandar, S. (1995). Ilmu Sosial Dasar. Bandung: PT. Eresco.

Musthofa, Q. (2017). Jilbab Sebagai Identitas Organisasi Islam Di Perguruan Tinggi. Wawasan: Jurnal Ilmiah Agama Dan Sosial Budaya, 2(2), 143-155. https://doi.org/10.15575/jw.v2i2.1680

Neliana, T. (2017). Faktor-Faktor yang mempengaruhi Tingkat Kelengkapan Pengungkapan Laporan Keuangan. Jurnal Riset Akuntansi Dan Keuangan, 5(2), 33-46.

Rahayu, L. M. (2016). Jilbab : Budaya POP dan Identitas Muslim di Indonesia. Ibda' : Jurnal Kebudayaan Islam, 4(1), 139-155.

Rahnama, A., Arani, Z. A. A., \& Arani, M. K. (2015). The Concept Of The Hijab In Islamic Texts and its Training Effects. Afaqi Din, 6(22), 37-54.

Sada, H. J. (2015). Konsep Pembentukan Kepribadian Anak Dalam Perspektif AlQur'an (Surat Luqman Ayat 12-19). Al-Tadzkiyyah: Jurnal Pendidikan Islam, 6(2), 253-272.

Saprudin, M., Mushlihin, \& Narulita, S. (2016). Motivasi Pemakaian Jilbab Mahasiswi Islam Universitas Negeri Jakarta. Jurnal Studi Al-Qur'an: Membangun Tradisi Berfikir Qur'ani, 12(2), 182-193. 
Setyawan, Y. H., \& Aryani, Y. A. (2017). Pengaruh Tuntutan Bersikap Etis dan FaktorFaktor Personal Terhadap Perilaku Auditor Pemerntah Daerah Dalam Menghadapi Tekanan Kerja. Jurnal Akuntansi Dan Bisnis, 17(2), 144-158.

Sopiah, Khobir, A., Zuhri, A., \& Mufidah, E. (2013). Persepsi Mahasiswi Terhadap Jilbab. Jurnal Penelitian, 5(2), 1-15.

Syaiful, I. A., \& Sari, A. V. K. (2017). Faktor-Faktor Yang Mempengaruhi Perilaku Konsumen dalam Bertransaksi di Media Sosial. Psikohumaniora: Jurnal Penelitian Psikologi, 1(1), 95-112.

Yamin, M. (2007). Profesionalisasi Guru \& Implementasi KTSP. Jakarta: Gaung Persada Press. 